\title{
Evaluation of Regional Emission Control Based in Photochemical Air Quality Modelling
}

\author{
Ángel Rodríguez et al.* \\ University of Santiago de Compostela, \\ Spain
}

\section{Introduction}

The growing use of natural gas as fuel both for industrial and domestic purposes implies an increment in the emissions of potential photochemical oxidants in the troposphere, particularly, nitrogen oxides $\left(\mathrm{NO}_{\mathrm{x}}\right)$. This effect can be higher in regions with a significant use of other fossil fuels for electricity production, such as coal fired power plants.

Therefore, even though the air quality levels of typical primary pollutants $\left(\mathrm{SO}_{2}\right.$ and coarse particles) can keep to acceptable values, synergies between additional $\mathrm{NO}_{\mathrm{x}}$ emissions, biogenic emissions and meteorological conditions can lead to the production of photochemical oxidants, such as $\mathrm{O}_{3}$. The application of meteorological and air quality modelling techniques to evaluate the impact of new $\mathrm{NO}_{x}$ sources in the $\mathrm{O}_{3}$ levels over a region can achieve a quantitative estimation of such impact, in terms of the variation of both $\mathrm{NO}_{x}$ and $\mathrm{O}_{3}$ levels in the region. This approach to the impact of new sources in air quality, now common for primary pollutants, requires the use of comprehensive air quality modelling in the evaluation of photochemical oxidants.

There are several comprehensive air quality models currently available that can be applied to this approach. However, the characteristics of new emission sources, regional conditions (i.e., terrain, sea influence) and pollutants of interest (i.e., photochemical oxidants) result in the selection of the most appropriate model for a particular problem (Chang et al., 1987; Song et al., 2010).

In this paper, comprehensive air quality modelling is applied to evaluate the effectiveness of emission control policy in a European Atlantic coastal region, with complex terrain and mixed land use, and a significant area of forestry. This region, located in the northwest of the Iberian Peninsula, includes both medium-sized cities and large coal fired power plants. Therefore, changes in both industrial and domestic emissions due to an increase in the use of the natural gas can affect the generation of photochemical oxidants, depending on the biogenic emissions (forestry) and typical meteorological conditions.

\footnotetext{
* Santiago Saavedra1 ${ }^{1}$, María Dios ${ }^{1}$, Carmen Torres ${ }^{1,2}$, José A. Souto ${ }^{1}$, Juan Casares ${ }^{1}$, Belén Soto ${ }^{3}$ and José L. Bermúdez ${ }^{3}$

${ }_{1}$ University of Santiago de Compostela, Spain.

${ }^{2}$ Now at University of Rovira i Virgili, Spain.

${ }^{3}$ Endesa Generación, Spain.
} 


\section{A case study}

Air pollution on local and regional scales is conditioned by a significant number of parameters grouped into three classes (Seinfeld and Pandis, 1998): topography, meteorology and precursors. Meteorology, which is implicitly linked to topography, plays an important role in air quality. Topography defines air flow paths and pollutant depositions. The influence of emission sources depends on both the amount of pollutants and the location of such sources (Beck et al., 1998). Therefore, the description of the area under study must include these three groups of parameters.

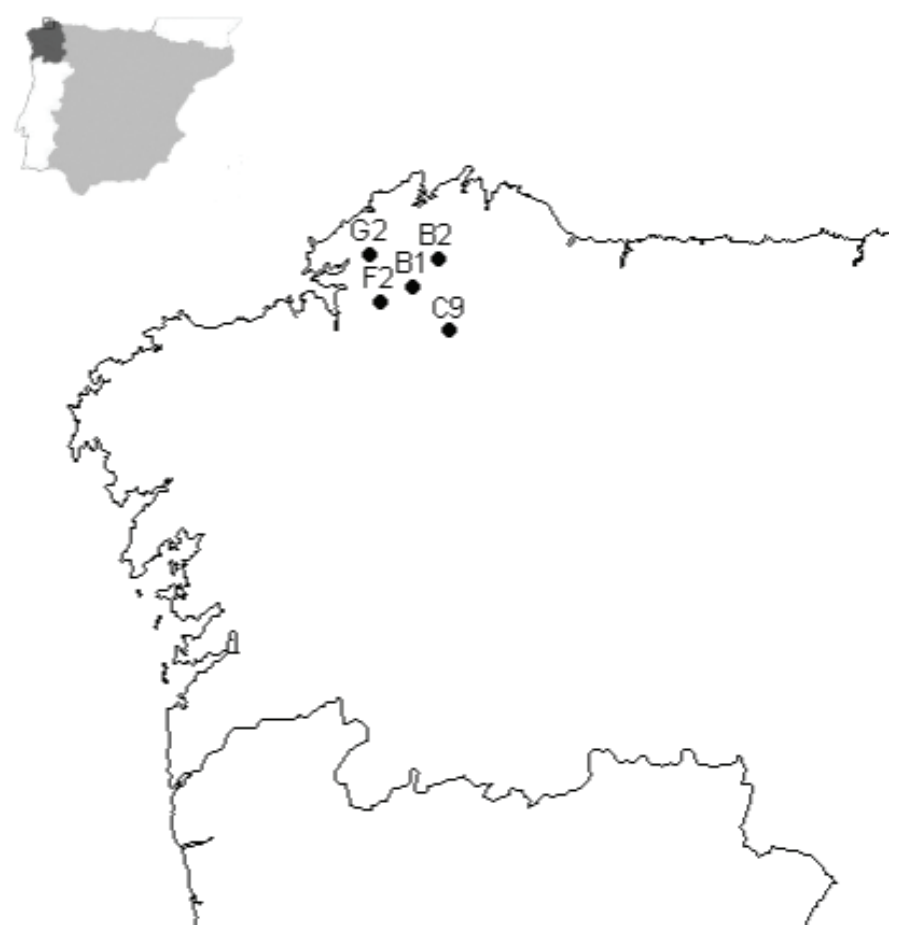

Fig. 1. Regional domain under study, including the Galician region. In addition, the location of the five $\mathrm{O}_{3}$ ground level concentration stations around As Pontes power plant, to be used identifying air quality episodes, is shown.

\subsection{Topography}

The area under study (figure 1) is characterized by a complex terrain environment, with large differences. The central part is defined by the As Pontes valley, from west to east, with the river Eume flowing along it. This valley is surrounded by the smooth Atlantic coast in the west and the more complex Cantabrian coast in the north; there are several mountains in the north-east (e.g. Xistral), and the valley boundaries are closed in the east by the Dorsal Gallega mountain range, up to $1000 \mathrm{~m}$ high. Along the south, the topography displays smooth, uniform, elevated plains. Therefore, it is a complex terrain, combining granitic mountains and valleys in the same environment. 


\subsection{Meteorology}

This region is characterized (Martínez Cortizas et al, 1999) by rains distributed throughout the year, with an annual precipitation rate between 1000 and $1600 \mathrm{~mm}$, mainly during autumn and spring, and sporadic in summertime (but not unusual, as there are isolated storms in the afternoons). Summers are mild, as the sea breeze refreshes the coastal areas and the height of the mountains regulates the temperature in the inner areas. Summer days are usually sunny, with low moisture and temperatures from 20 to $30^{\circ} \mathrm{C}$. On the other hand, heat waves are not usual in summer, and they only last a few days, as the proximity of the coast keeps the average temperature at $20-25^{\circ} \mathrm{C}$, with higher temperatures (up to $30{ }^{\circ} \mathrm{C}$ ) in the interior valleys.

Main winds come from the SW and NW during winter and autumn, when pressure is low, whereas high pressure, typical in summertime, usually corresponds to NE winds. The atmosphere-topography interaction is very important in this environment, especially the mountains, which affect the production of rain, and the complex coastal topography, which increases the sea breeze.

\subsection{Sources of ozone precursors}

The main ozone precursors are taken to be oxidized nitrogen and volatile organic compounds. Sources of these precursors located in the area under study (Casares et al., 2005) can be divided into point sources (usually, industrial sources) and diffuse sources. Industrial sources include the Artabric Arc Industrial Belt (located on the west coast, including the cities of A Coruña and Ferrol), where there are various sectors such as petroleum refining, energy (thermal power plants and cogeneration units), wood, food and metallurgy. Other sparse emission sources, such as industrial waste plants, are also included.

The main diffuse sources are traffic and biogenic emissions from cattle farming and forest cultivation (mainly, eucalyptus and pines). However, as ozone can be transported over long distances, it is necessary to take into account not only the local sources, but also sources in neighbouring regions (Asturias, Castilla-León and Portugal), and even further afield. This was done by analyzing air quality levels in those regions, as a characteristic of air masses that can be carried to the area under study. In order to evaluate the impact of emission changes on air quality, three typical meteorological conditions favourable to increasing tropospheric ozone levels are identified in the NW of the Iberian Peninsula. From these typical conditions, three different periods were selected as reference episodes to apply a comprehensive air quality modelling of different emission scenarios: Episode 1 (14-23 July 2002), episode 2 (16-24 March 2003), and episode 3 (12-22 September 2003). The characterization of these episodes shows a different principal origin of ozone peaks depending on the meteorological conditions: episode 1, North of Portugal; episode 2, Castilian plateau; and episode 3, Galicia.

\section{Air pollution episodes}

\subsection{Air quality data}

Hourly ground level concentration registers of $\mathrm{O}_{3}, \mathrm{NO}_{x}$ and $\mathrm{NO}_{2}$ were collected for the 3-year period 2002-2004. First of all, validated data were obtained from 10 air quality stations included in the Galician Air Quality Network, in order to identify the $\mathrm{O}_{3}$ episodes, and to obtain a first approach to them. These stations are mainly rural, with only 
background influence or, sometimes, influence from distant industrial sources. After identifying the main $\mathrm{O}_{3}$ episodes, the possible influence from surrounding regions was studied by looking at more air quality stations: 19 air quality stations from the National Portuguese Air Quality Network, 18 from the Castilla-León Regional Air Quality Network, and daily average data from the Asturias Regional Air Quality Network (as hourly data were not available).

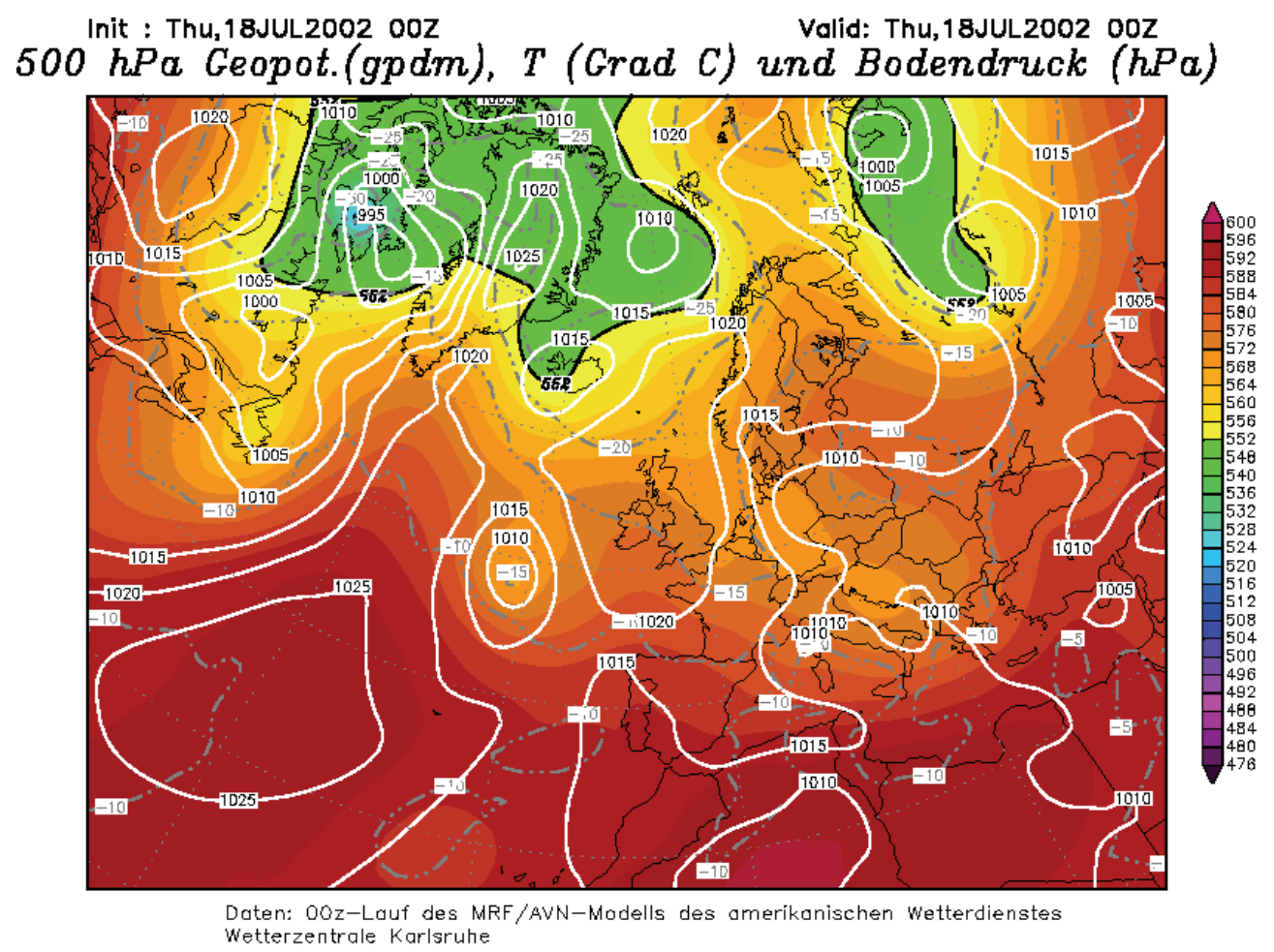

Fig. 2. An example of a synoptic chart provided by Wetterzentrale, applied in the classification of ozone air pollution episodes in the region under study.

\subsection{Meteorological dataset}

The regional scale meteorological analysis of the episodes was done by means of synoptic maps (Font-Tullot, 1983; Castell et al., 2004), in order to identify the synoptic conditions with more influence in the tropospheric ozone episodes over Galicia.

Synoptic charts (figure 2) were collected from the National Center for Environmental Prediction (NCEP, USA) reanalysis. These charts include synoptic observations which are interpolated and recalculated by diagnostic models, so they are more trustworthy than forecast charts. In these NCEP charts, several variables were included, over geopotentials at $500 \mathrm{mb}$ and sea level pressure; in addition, temperature maps at 500 and $850 \mathrm{mb}$ are included. These charts are routinely collected by the Wetterzentrale (German Meteorological Office) on its web page (www.wetterzentrale.de). 
Regional meteorology was completed by observations of surface temperature and wind, precipitations and other typical meteors (clouds, storms, fog, etc.) from Wetterzentrale maps based in European meteorological stations with $6 \mathrm{~h}$ observations.

After identifying the ozone episodes, local meteorological observations were collected, in order to obtain a more comprehensive analysis of the meteorological influence over local pollution episodes, taking into account local phenomena, such as katabatic and anabatic winds, sea breeze and thermal inversions, which are not represented on a synoptic scale. This is an important issue in a complex terrain like Galicia.

Local surface meteorological measurements were taken on an hourly basis and included surface temperature $(2 \mathrm{~m})$ and surface wind speed and direction $(10 \mathrm{~m})$ from five stations of the As Pontes Power Plant air quality network, integrated in the Galician regional air quality network. These data were extended with hourly measurements from A Mourela station (D1 station, close to the Power Plant), providing temperatures at 2, 10, 30 and 80 agl-m (which is useful for stability classification), wind at 10 and 80 agl-m, solar radiation and precipitation.

\begin{tabular}{lcc}
\hline \hline \multicolumn{1}{c}{ Episode period } & $\begin{array}{c}\text { Maximum hourly } \\
\mathrm{O}_{3} \text { glc date/time }\end{array}$ & $\begin{array}{c}\text { Maximum hourly } \\
\mathrm{O}_{3} \text { glc }\left(\mu \mathrm{g} / \mathrm{m}^{3}\right)\end{array}$ \\
\hline 14-23 July & Year 2002 & 201 \\
11-17 August & 18 July - 16 UTC & 142 \\
23-04 September & 14 August - 16 UTC & 157 \\
09-18 September & 02 September - 16 UTC & 136 \\
21-30 September & 14 September - 14 UTC & 145 \\
\hline & 27 September - 17 UTC & 148 \\
\hline 16-24 March & Year 2003 & 161 \\
26-01 June & 21 March - 16 UTC & 210 \\
18-24 June & 29 May - 05 UTC & 139 \\
06-13 July & 20 June - 17 UTC & 174 \\
30-16 August & 08 July - 15 UTC & 193 \\
12-22 September & 07 August - 17 UTC & \\
\hline & 16 September - 15 UTC & 170 \\
\hline 14-22 May (12) & Year 2004 & 156 \\
31-11 June (13) & 19 May - 15 UTC & 196 \\
12-19 June (14) & 05 June - 15 UTC & 181 \\
28-05 August (15) & 17 June - 16 UTC & \\
\hline
\end{tabular}

Table $1 . \mathrm{O}_{3}$ episodes identified in the region under study, from the glc measurements available, taking dual criteria into account: either $150 \mu \mathrm{g} / \mathrm{m}^{3}$ threshold or significant rise of glc in a short period.

\subsection{Air pollution episodes}

A coarse selection of episodes with tropospheric ozone levels higher than usual (risky episodes) was made with reference to the air pollution measurement dataset in the domain for 2002, 2003 and 2004. These measurements correspond to the five air quality stations located mainly in rural areas around As Pontes Power Plant (figure 1), and distributed over 
2 to $30 \mathrm{~km}$ away from the industrial site. These stations are integrated into the Galician air quality network, controlled by the regional government.

In order to select $\mathrm{O}_{3}$ risky episodes, two criteria were adopted: (a) tropospheric ozone threshold of $150 \mu \mathrm{g} / \mathrm{m}^{3}$, as an hourly average ( $20 \%$ below first European Union legal threshold); (b) persistent rise of tropospheric ozone levels in several stations, independently on the absolute values achieved.

The period under study for each episode was established as at least 7 days around the maximum concentration, which can be extended depending on the concentration tendency (persistence either in ascent or descent). This period is important because of the time required by ozone production and destruction, taking into account the influence of meteorological conditions in these chemical phenomena. In fact, the duration of an episode was extended until it was clear that clean air masses with low ozone levels were achieved in the domain, ensuring that the episode had ended.

With these criteria, 15 tropospheric ozone air pollution episodes (table 1) were identified in the domain, 5 in the year 2002, 6 in 2003, and 4 in 2004. All the episodes were observed between March and September. Episodes lasted from 7 to 18 days. These episodes can be represented by three typical meteorological conditions which are favourable to the increase in tropospheric ozone levels, and are identified in the NW of the Iberian Peninsula. Therefore, three different periods were selected as reference episodes to apply a comprehensive air quality modelling to different emission scenarios: Episode 1 (14-23 July 2002), episode 2 (16-24 March 2003), and episode 3 (12-22 September 2003). The characterization of these episodes shows a different main origin of ozone peaks depending on the meteorological conditions: episode 1, North of Portugal; episode 2, Castilian plateau; and episode 3, Galicia.

\section{Air quality modelling}

In this paper, the CAMx model (Environ International Co., 2010; Song et al., 2010) was selected because of its capacity to integrate large aloft emissions from power plant stacks in the model grid with area emissions representing sparse sources (domestic and transport). This approach is essential to obtain a good representation of the impact from large point sources in regional air quality.

The CAMx model is coupled with the PSUN/NCAR MM5 meteorological model (Grell et al., 1995) in order to provide the required meteorological conditions for both dispersion and chemical transformation of pollutants.

\subsection{Simulation domains}

The area under study covers Galicia, a region in the north-west of Spain, although the simulation domain has to cover a larger area in order to minimize the boundary effect on the model results. However, because of the high resolution required in the complex region under study, applying a high resolution to the larger simulation domain leads to heavy computing work. Therefore, the use of the nesting technique is highly recommended.

Thus, a coarse resolution grid (with a resolution of $27 \times 27 \mathrm{~km}^{2}$ ) covering the Iberian Peninsula (see figure $3 a$ ) is defined. Simulation results over this larger domain were applied as input to a nested inner grid (with a resolution of $9 \times 9 \mathrm{~km}^{2}$, see figure $3 b$ ), following a oneway nesting approach; i.e, it is thought that the meteorology over the inner grid does not substantially affect the meteorology over the outer grid. 


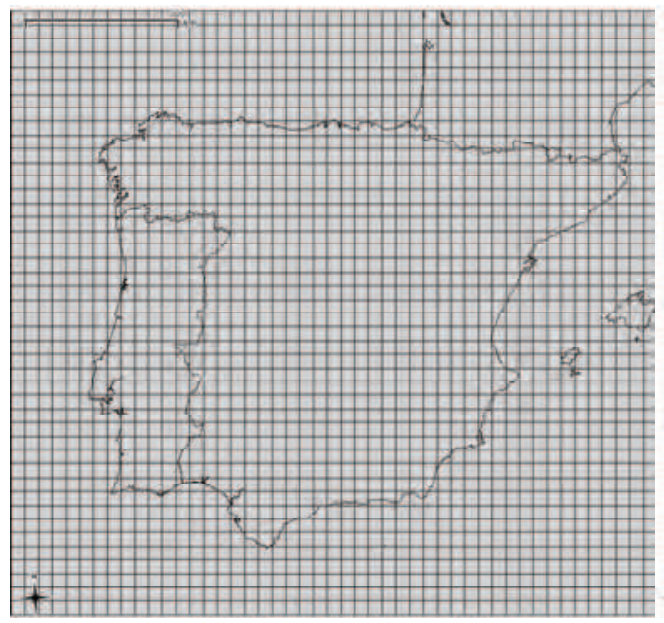

(a)

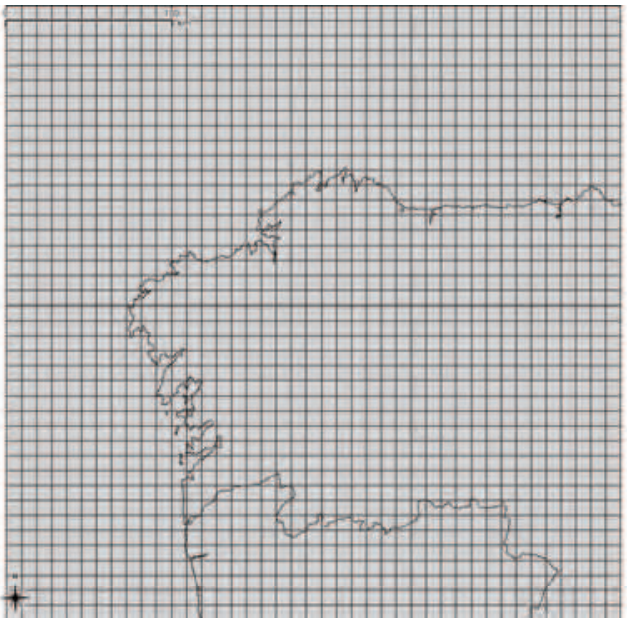

(b)

Fig. 3. Simulation grids covering (a) the Iberian Peninsula, and (b) the northwest of the Iberian Peninsula, including the Galician region.

An additional problem in the application of air quality models relates to geographical projections. These models are usually solved over plane grids, even though the Earth surface is curved. In order to define the plane representation of the Earth surface, the following parameters are defined: (a) geodesic datum, i.e., the shape and dimensions of the ellipsoid to be represented; in our case, it is the Earth. The European Datum 50 (ED50) was adopted; (b) geographical projection, i.e., a sorted relationship between the locations over the curved surface (Earth's surface) and the plane surface over the simulation grid is defined. In this case, UTM ("Universal Transverse Mercator") projection referring to 29 North Time Zone is used. As a result, the Iberian Peninsula domain is represented by a grid (figure 3a) with $44 \times 47$ cells. The inner domain is represented by a grid (figure $3 b$ ) with $41 \times 41$ cells. However, the computing work required to solve the inner grid is higher, because of the Courant number; i.e., the smaller the size of the grid cells is, the shorter the time step to be applied in the numerical integration of the model equations during the same simulation period. Therefore, in the inner grid, it is necessary to solve the equations more often to simulate the same period. This is a significant limitation in the application of the Eulerian models (such as the CAMx model) in the simulation of the air quality with high resolution grids.

\subsection{Emission inventories}

As the simulation domains cover the Iberian Peninsula, including the Galician region, a 2001 annual emission inventory was developed by combining the top-down inventory from EMEP (Iberian Peninsula) and the bottom-up industrial emission EPER inventory from REGADE (Casares et al., 2005). SMOKE (The Institute for the Environment, 2003) was applied for speciation, time and spatial segregation of industrial emissions.

In addition, a 2010 annual emission projection (table 2) was carried out using changes in industrial emissions, due to the application of Best Available Techniques (BATs) to reduce emissions from the old power plants, and the installation of new combined cycles in the 
region. This new scenario follows the legal restrictions currently approved by the Government, so changes should lead to a significant reduction in primary pollutant levels $\left(\mathrm{SO}_{2}, \mathrm{PM} 10\right)$; however, secondary pollutants, such as ozone, are affected by extremely nonlinear physical and chemical processes that should be considered when evaluating the effect of emission changes over their levels. These non-linear processes can be simulated by a comprehensive air quality model.

\begin{tabular}{|c|c|c|c|}
\hline \multicolumn{4}{|c|}{$\mathrm{NO}_{\mathrm{x}}(\mathrm{Tm} /$ year $)$} \\
\hline Source & $\begin{array}{c}2001 \\
\text { inventory }\end{array}$ & $\begin{array}{c}2010 \\
\text { projection }\end{array}$ & Change \\
\hline Sabón & $\begin{array}{c}833 \\
- \\
\end{array}$ & $\begin{array}{c}738 \\
2764 \\
\end{array}$ & $+320 \%$ \\
\hline Meirama & 9059 & 1604 & $-83 \%$ \\
\hline As Pontes & $\begin{array}{c}20035 \\
-\end{array}$ & $\begin{array}{l}6863 \\
2764\end{array}$ & $-52 \%$ \\
\hline
\end{tabular}

Table 2. $\mathrm{NO}_{\mathrm{x}}$ emission changes between year 2001 (reference inventory) and 2010 (projected inventory), in the three power plants.

As the main differences in the industrial emissions of ozone precursors between 2001 inventory and 2010 projection, NMVOCs shows an increment of $6.6 \%$ and $\mathrm{NO}_{\mathrm{x}}$ a reduction of $27 \%$. In addition, a significant spatial redistribution of $\mathrm{NO}_{\mathrm{x}}$ industrial sources is observed (table 2) due to: (a) fuel changes in the three Galician high stack power plants, which have reduced their $\mathrm{NO}_{\mathrm{x}}$ emissions by $50 \%$; (b) two planned combined cycles, with $\mathrm{NO}_{\mathrm{x}}$ emissions at lower height (less than $200 \mathrm{~m}$ ).

In addition to the anthropogenic contribution, the role of volatile organic compounds (VOCs) in tropospheric ozone production is also taken into account, especially for biogenic organic species (BVOCs), such as isoprene and terpenes (Makar et al., 1999; Geron et al., 2000). These BVOCs emissions were estimated by using MEGAN model (Guenther et al., 1995), as this model uses a high resolution functional plant distribution $\left(1 \times 1 \mathrm{~km}^{2}\right)$ and the results can be processed as input (such as time-varying emissions) to the CAMx model.

\subsection{Emission integration}

\subsubsection{Simulation grids}

For a realistic representation of anthropogenic emissions in the region, different emission inventories were combined: EMEP for the Peninsula domain and EPER-REGADE for the Galician domain. Both inventories were adapted to the corresponding nested grids using SMOKE, in order to provide the emission input to the CAMx model.

a. Peninsula domain

In the Peninsula domain, only the EMEP emission inventory was applied. However, this inventory is aggregated in a $50 \mathrm{~km}$ resolution grid with the origin in the North Pole; therefore, it must be adapted to the Peninsula domain simulation grid. This adaptation has been done by applying the GIS extension of the PortgreSQL database, with a distribution weighted to the surface area (figure 4).

b. Galician domain

In the Galician domain, EMEP emissions were applied for CORINAIR sources, other than S1 and S3, following the same process as in the Peninsula domain. With the EMEP inventory 

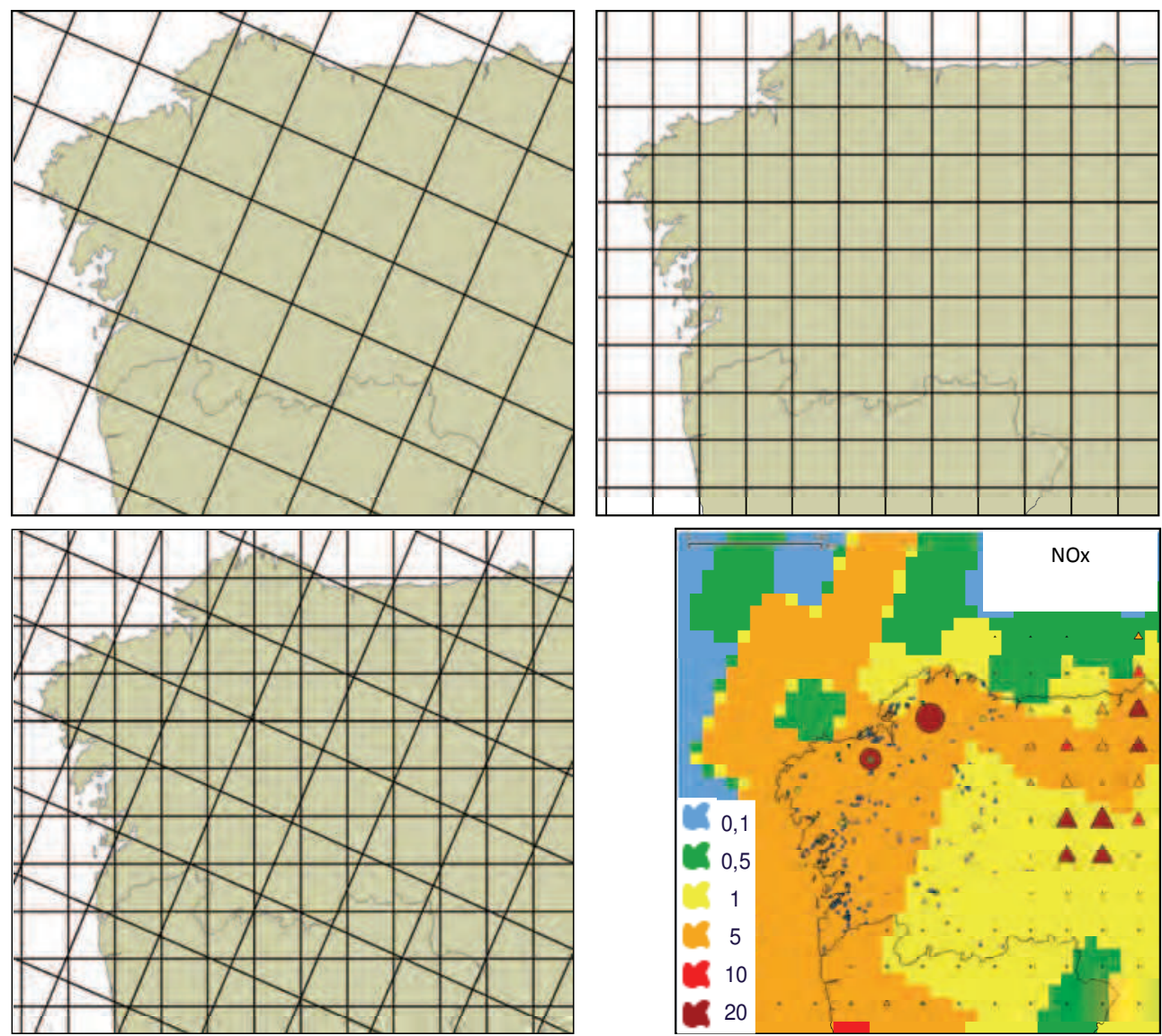

Fig. 4. Adapting the EMEP emissions grid to the simulation grid over the Peninsula domain.

adapted to both simulation grids, all data have been integrated into SMOKE in order to combine the different anthropogenic emissions and to provide the emission input to the CAMx model.

For CORINAIR S1 and S3 sources, the EPER-REGADE Galician inventory was also integrated into SMOKE as a bottom-up point sources inventory. In particular, the REGADE inventory applies to the detailed SCC classification from EPA, with equivalences in the coarser CORINAIR sources classification. In addition, this procedure is important in order to obtain an accurate geographical location of these industrial sources and, particularly, to take into account their different stack heights in the CAMx algorithm for elevated point sources.

\subsubsection{Time-varying anthropogenic emissions}

Depending on the type of emission sources, the variation in time of their emissions is very different. Industrial emissions are normally quite steady-state. However, non-industrial emissions present varying behaviour depending on their specific activity; therefore, more 
complex temporal profiles for the non-industrial emissions have been used, depending on the simulation domain, which are:

Peninsula domain: The industrial emissions from S1 and S3 CORINAIR sectors are applied as steady state annually, weekly and daily. For the remaining emissions (sectors), no annual or weekly variations were used, but a daily profile with daytime emissions three times higher than night-time emissions was applied.

Galician regional domain: As the industrial emissions for this domain are available from the EPER-REGADE inventory with SCC EPA classification, temporal profiles following EPA recommendations were applied. These profiles are included in the SMOKE package for processing SCC classified emissions.

\subsubsection{Aloft anthropogenic emission distribution}

The height of emissions is a significant factor in the results of air quality models (Kumar and Russell, 1996), especially for large point sources with stacks. In fact, CAMx model considers point sources and surface sources separately, as the model includes a plume rise algorithm to estimate the increment of the emission height for elevated point sources. However, this algorithm requires complex datasets that are not always available. Therefore, depending on the precision required in each of the simulation grids, different approaches to entering the emission height in the model are used, as follows.

Peninsula domain: As the EMEP inventory only includes the geographical location of emissions, their height is assumed from the group of emission sources. Thus, S1 and S3 industrial sectors emissions from every grid cell are converted to one virtual point source by cell, and every virtual point is considered to be emitted at 200 agl-m (as an average value); the rest of the emissions over every cell are taken as surface level emissions.

Galician regional domain: The EPER-REGADE inventory includes all the dataset required to define the stack heights and their plume rises. This dataset is included in the SMOKE package to distinguish surface and elevated sources and to provide the CAMx with the required information for the elevated sources.

\subsubsection{Chemical speciation}

Emission inventories include a chemical speciation which is usually less detailed than required by the chemical mechanisms applied in the air quality models (Carter, 1990). Therefore, it is necessary to segregate some groups of emissions in order to obtain an approximation to the actual chemical mechanism speciation. In this work, Carbon Bond IV (CBIV) chemical mechanism included in the CAMx model is applied. Therefore, for an initial emission speciation to this mechanism, the Spcmat tool from SMOKE is used.

\section{Results}

Simulations were performed with CAMx, with two nested grids covering the Iberian Peninsula (27x27 km² resolution) and Galicia ( $9 \times 9 \mathrm{~km}^{2}$ resolution), using chemical boundary conditions provided by GOCART and MOZART data. Meteorological inputs were provided by PSUN/NCAR MM5 one-way nesting simulations at $27 \times 27 \mathrm{~km}^{2}$ and $9 \times 9 \mathrm{~km}^{2}$ resolutions, using NCEP re-analysis as initial and boundary conditions.

Results for the three different reference episodes (figure 7) show that changes in industrial emissions will produce a significant reduction in the nocturnal ozone glc around the new 


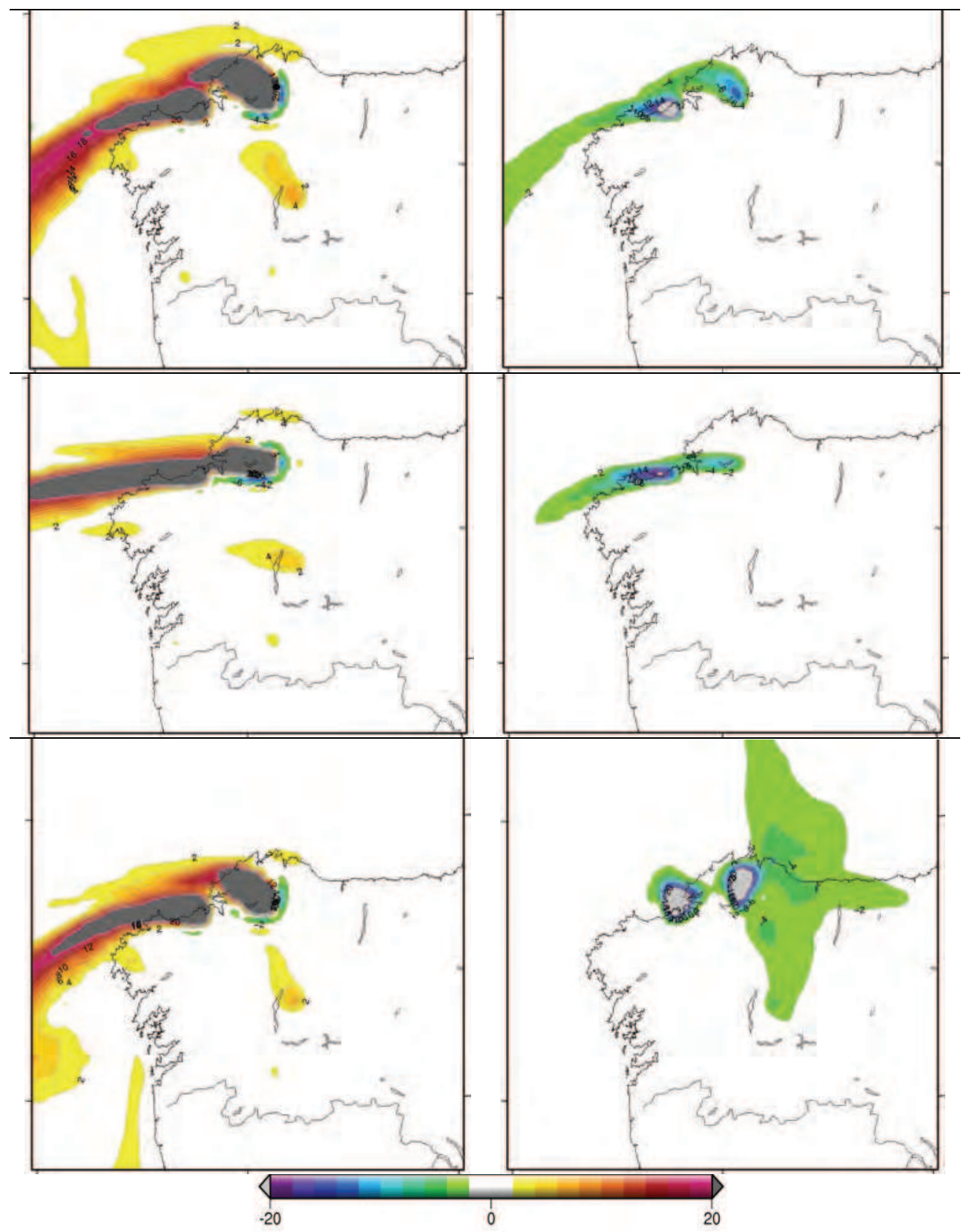

Fig. 7. Relative differences (\%) in nocturnal $\mathrm{NO}_{2}$ (left) and $\mathrm{O}_{3}$ (right) glc over Galicia between 2001 emission inventory and 2010 emission projection simulations at the central date of the episodes under study. From above to below: 18/July/2002 - 04 UTC, 21/March/2003 - 03 UTC, and 17/September/2003 - 03 UTC, respectively. 


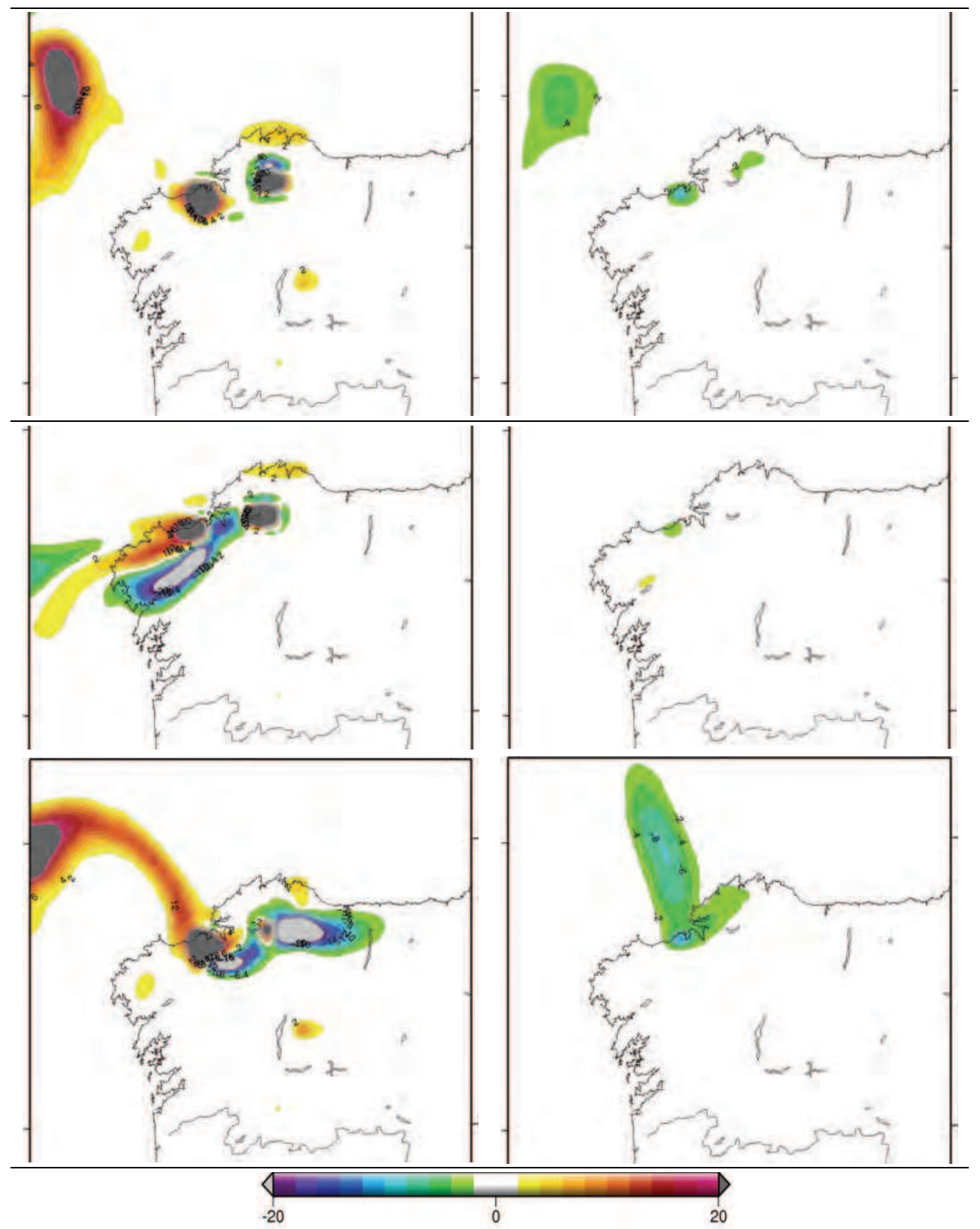

Fig. 8. Relative differences (\%) in diurnal $\mathrm{NO}_{2}$ (left) and $\mathrm{O}_{3}$ glc (right) over Galicia between 2001 emission inventory and 2010 emission projection simulations at the central date of the episodes under study. From above to below: 18/July/2002 - 16 UTC, 21/March/2003 - 14 UTC, and 17/September/2003 - 14 UTC, respectively. 
combined cycles (As Pontes and Sabón) and surrounding areas sporadically affected by their plumes; this reduction is not observed during the diurnal period (figure 8). At least for episodes 1 and 2, nocturnal reduction is due to the significant increment of $\mathrm{NO}_{x}$ glc around both sources (because their stacks are lower than the old coal fired power plant stacks). In episode 3, the ozone reduction is more sparse, even in an opposite direction (east) to the $\mathrm{NO}_{\mathrm{x}}$ industrial plumes; this may be due to lower winds and higher dispersion during this episode.

No significant changes (figure 8) are observed in the diurnal ozone glc; only a small reduction over the local areas affected by the plumes from the aloft sources (As Pontes and

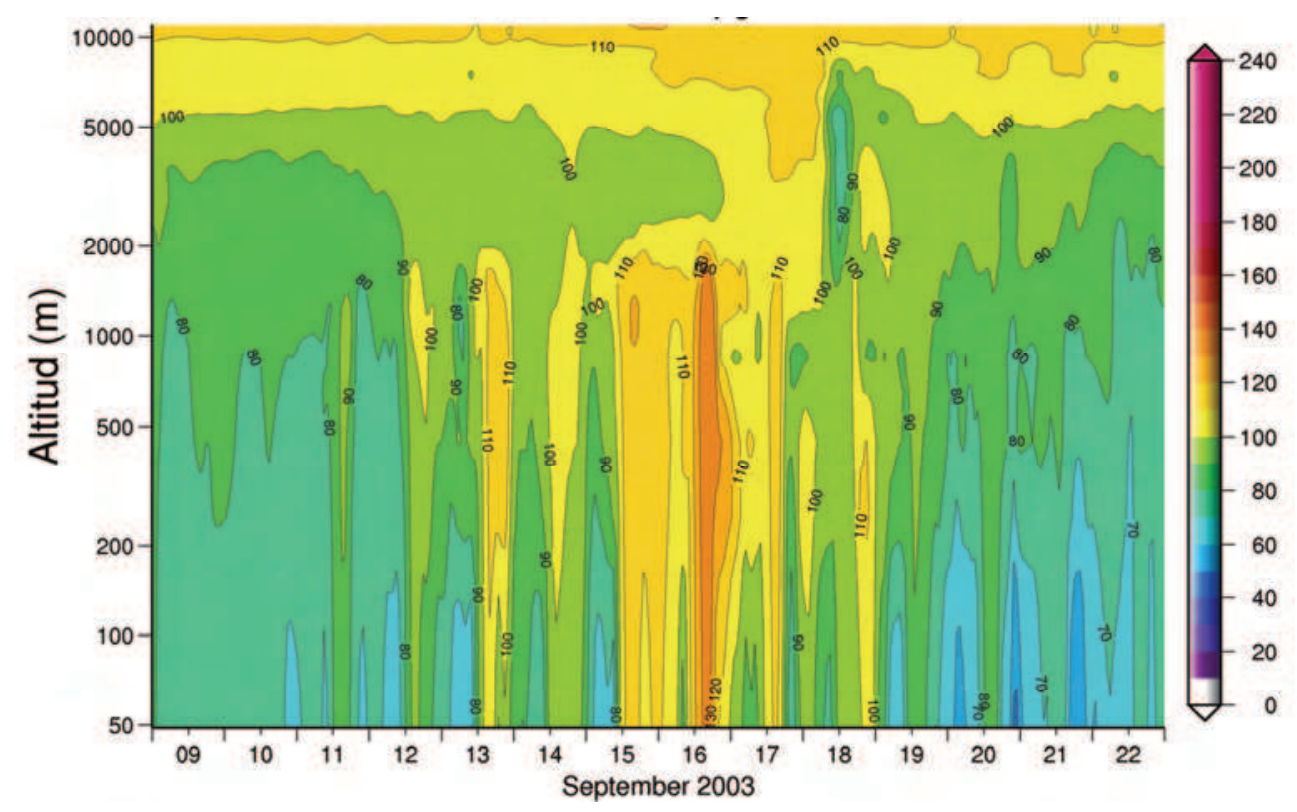

Fig. 9. Relative differences (\%) in nocturnal $\mathrm{O}_{3}$ concentration over the maximum glc location along the episode 9-22 September 2003, between 2001 emission inventory and 2010 emission projection simulations. 
Meirama), as the combined effect of the reduction of $\mathrm{NO}_{x}$ emissions aloft (reducing diurnal ozone production) and the increment of $\mathrm{NO}_{x}$ surface emissions (increasing diurnal ozone production and consuming nocturnal ozone).

However, ozone glc reduction is accompanied by an increment in the aloft $\mathrm{O}_{3}$ levels; as an example, figure 9 shows an increment in aloft $\mathrm{O}_{3}$ concentration and, simultaneously, a decrease in $\mathrm{O}_{3}$ concentration at lower levels (including ground level). At the same time, there is no significant changes in nocturnal ozone glc in the rest of the region, even though a significant reduction of $\mathrm{NO}_{x}$ emissions aloft is expected from the old high stack coal fired power plants (see table 2); this is because aloft emissions are dispersed above the nocturnal stable layer.

Changes in air quality are more significant in $\mathrm{NO}_{2}$ glc: there is an increment of $\mathrm{NO}_{2}$ glc around Sabón and As Pontes sources (figures 7 and 9), due to the contribution of surface emissions around these areas.

\section{Conclusions}

From the comparison of 2001 emission inventory and 2010 emission projection at Galician region, simulation results from the CAMx model show a change in ozone distribution. Surprisingly, concentration downwind from the combined cycles is decreased because of their lower stacks (with respect to the old coal and fuel oil power plants), and slightly decreased in remote areas. This effect is especially significant during nocturnal periods.

On the other hand, simulation results show an increment of $\mathrm{O}_{3}$ aloft concentration, which can be transported to neighbouring regions and increase their glc. This effect is not usually taken into account in the current impact assessment, which is based on either estimated or measured pollutant glc close to the sources. Therefore, although the strategy of emission reduction in this region can achieve better results on a local scale, it could lead to an increase in the contribution of this region to the $\mathrm{O}_{3}$ levels in the vicinity.

At the same time, an increment in the $\mathrm{NO}_{x}$ ground level concentration is expected both due to the rise in surface $\mathrm{NO}_{x}$ emissions and the lower stack height of the new industrial sources (combined cycles). Therefore, although ozone glc achieves local reductions along the $\mathrm{NO}_{\mathrm{x}}$ industrial plumes, the increment of $\mathrm{NO}_{\mathrm{x}}$ levels can lead to worse air quality in other areas not affected by these industrial plumes (i.e. urban and rural areas far away from these sources). However, simulation results show no significant effect due to $\mathrm{NO}_{\mathrm{x}}$ in the glc values.

\section{Acknowledgements}

This work has been financially supported by the Spanish Research \& Development Programme, Ministry of Science and Technology, under project CTQ15481-PPQ, and Endesa Generación S.A.. Research grants of the "María Barbeito" Programme (Xunta de Galicia) to Angel Rodríguez and María Dios, are acknowledged.

Hourly ground level concentration measurements were provided by the Portuguese Ministry of Environment, the Spanish Ministry of Environment, the Galician Regional Department of Environment, the Castilla-León Regional Department of Environment, and Endesa Generación, S.A.. 


\section{References}

Beck, J.P., Krzyzanowski, M., Koffi, B., 1998: Tropospheric Ozone in the European Union The consolidated report, Topic Report no. 8/1998, European Environment Agency.

Carter, W. P. L., 1990: A detailed mechanism for the gas-phase atmospheric reactions of organic compounds, Atmospheric Environment, 24, pp. 481 - 518.

Casares, J. J., Rodríguez, R., Maceira, P., Souto, J. A., Ramos, S., Costoya, M. A., Sáez, A., Vellón, J.M., 2005: Inventario, Análisis y Proyección de las Emisiones Atmosféricas Industriales de Galicia, Ed. Servizo de Publicacións e Intercambio Científico, Universidade de Santiago de Compostela, Santiago de Compostela.

Castell, N., Mantilla, M., Fernández, F., López, E., 2004: Distribución espacial y temporal de los episodios de contaminación por ozono y su relación con las situaciones sinópticas en la vertiente mediterránea, Proyectos y métodos actuales en Climatología, Asociación Española de Climatología, 2004, Serie B, 1, pp. 600-606.

Chang, J. S., Brost, R. A., Isakson, I. S. A., Madronich, S., Middleton, P., Stockwell, W. R., Walcek, C. J., 1987: A three-dimensional Eulerian acid deposition model: physical concepts and formulation, Journal of Geophysical Research, 92, pp. 14651 - 14700.

Environ International Co., 2010: CAMx: Comprehensive Air Quality Model with Extensions - User's Guide. Novato (Ca), USA.

Font-Tullot, I., 1983: Climatología de España y Portugal, Instituto Nacional de Meteorología, Madrid.

Geron, C., Guenther, A., Sharkey, T., and Arnts, R. R., 2000: Temporal variability in basal isoprene emission factor, Tree Physiology, 20(12), pp. 799-805.

Grell, G.A., Dudhia, J., Stauffer, D.R.,1995: A description of the Fifth-Generation Penn State / NCAR Mesoscale Model (MM5), Technical Report NCAR/TN-398+STR, NCAR, Boulder (Co), USA.

Guenther, A., Hewitt, C. N., Erickson, D., Fall, R., Geron, C., Graedel, T., Harley, P., Klinger, L., Lerdau, M., Mckay, W. A., Pierce, T., Scholes, B., Steinbrecher, R., Tallamraju, R., Taylor, J., and Zimmerman, P. A., 1995: Global-Model of Natural Volatile Organic-Compound Emissions, Journal of Geophysical Research, 100(D5), pp. 8873-8892.

Kumar, N., Russell, A.G., 1996: Development of a computationally efficient, reactive subgrid-scale plume model and the impact in the northeastern United States using increasing levels of chemical detail, Journal of Geophysical Research, 101, pp. 16737 $-16744$.

Makar, P., Fuentes, J., Wang, D., Staebler, R., and Wiebe, H. 1999: Chemical processing of biogenic hydrocarbons within and above a temperate deciduous forest, Journal of Geophysical Research, pp. 104(D3), pp. 3581- 3603.

Seinfeld, J. H., Pandis, S.N., 1998: Atmospheric Chemistry and Physics, From Air Pollution to Climate Change, John Wiley and Sons, Inc., New York.

Song, J et al., 2010: Ozone response to emission changes: a modeling study during the MCMA-2006/MILAGRO Campaign, Atmospheric Chemistry and Physics, 10, pp. 3827-3846

Sparse Matrix Operator Kernel Emissions (SMOKE), 2006: SMOKE v2.3 User's Manual, Carolina Environmental Program, University of North Carolina at Chapel Hill 
The Institute for the Environment, 2003: SMOKE v2.0 User Manual. CEP (Carolina

Environmental Program). The University of North Carolina at Chapel Hill. 


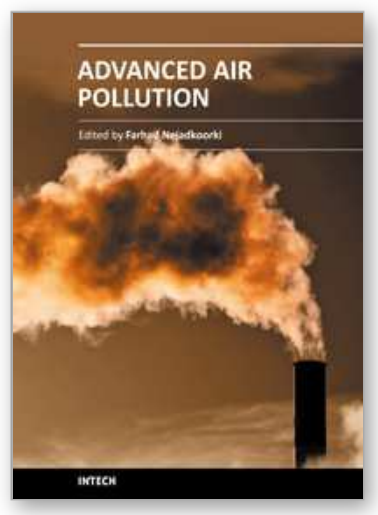

\author{
Advanced Air Pollution \\ Edited by Dr. Farhad Nejadkoorki
}

ISBN 978-953-307-511-2

Hard cover, 584 pages

Publisher InTech

Published online 17, August, 2011

Published in print edition August, 2011

Leading air quality professionals describe different aspects of air pollution. The book presents information on four broad areas of interest in the air pollution field; the air pollution monitoring; air quality modeling; the GIS techniques to manage air quality; the new approaches to manage air quality. This book fulfills the need on the latest concepts of air pollution science and provides comprehensive information on all relevant components relating to air pollution issues in urban areas and industries. The book is suitable for a variety of scientists who wish to follow application of the theory in practice in air pollution. Known for its broad case studies, the book emphasizes an insightful of the connection between sources and control of air pollution, rather than being a simple manual on the subject.

\title{
How to reference
}

In order to correctly reference this scholarly work, feel free to copy and paste the following:

Angel Rodríguez,1Santiago Saavedra, Maria Dios, Carmen Torres, José A. Souto, Juan Casares, Belén Soto and José L. Bermúdez (2011). Evaluation of Regional Emission Control Based in Photochemical Air Quality Modelling, Advanced Air Pollution, Dr. Farhad Nejadkoorki (Ed.), ISBN: 978-953-307-511-2, InTech, Available from: http://www.intechopen.com/books/advanced-air-pollution/evaluation-of-regional-emission-control-basedin-photochemical-air-quality-modelling

\section{INTECH}

open science | open minds

\author{
InTech Europe \\ University Campus STeP Ri \\ Slavka Krautzeka 83/A \\ 51000 Rijeka, Croatia \\ Phone: +385 (51) 770447 \\ Fax: +385 (51) 686166 \\ www.intechopen.com
}

\author{
InTech China \\ Unit 405, Office Block, Hotel Equatorial Shanghai \\ No.65, Yan An Road (West), Shanghai, 200040, China \\ 中国上海市延安西路65号上海国际贵都大饭店办公楼 405 单元 \\ Phone: +86-21-62489820 \\ Fax: +86-21-62489821
}


(C) 2011 The Author(s). Licensee IntechOpen. This chapter is distributed under the terms of the Creative Commons Attribution-NonCommercialShareAlike-3.0 License, which permits use, distribution and reproduction for non-commercial purposes, provided the original is properly cited and derivative works building on this content are distributed under the same license. 